\title{
Moldova looks westwards, and wins?
}

\begin{abstract}
This article explores Moldovan strategy regarding the European Union, building on a discussion of the Action Plan which Moldova signed with the EU in 2005. The author first cites at length the results of a survey of the opinions of a representative sample of Moldovans on issues including their attitudes towards the EU, their sources of information and knowledge about the EU, including the European Neighbourhood Policy, and their opinions on the implementation of political dialogue and democratic reforms and the factors which are slowing reform. A clear factor which needs to be addressed if Moldova is to improve its reform record is the effective implementation of agreed changes. The author outlines a number of issues in the area of integration which experts believe must be confronted, on the basis that Moldova's location in the south-east of Europe cannot be taken for granted in terms of the superficial advantages it offers the integration project, and argues that rewards and privileges must be delivered where the specific and clear demands of the EU are met.
\end{abstract}

Keywords: European integration, Action Plan, European Neighbourhood Policy, transformation and reform, technical assistance programmes, geo-strategic politics, freedom of movement.

\section{Background}

European integration remains one of the highest priorities in Moldovan foreign policy. At least, this is what the presidency, government and the parliament of this country have been stating for several years; precisely, since 2005, soon after the elections, when all political forces in the Parliament of Moldova endorsed a Joint Statement that defined the EU as a strategic priority of the country. However, this is a process which requires a great deal of effort from the applicant country and a long process of reformation and adjustment to EU norms and regulations.

When, in December 2004, the EU agreed to sign a new round of Action Plans with its country neighbours, this was presented as a policy that aimed to avoid isolation for those who remained outside the EU's borders, with a view to providing them with targeted incentives towards further integration. However, the EU very soon afterwards decided to stop further enlargement, with fatigue quickly capturing even the most ardent supporters of the EU's eastwards enlargement. Action Plans remain the only instrument to deal with the challenges of transition across the EU's peripheries, in which political will and public support are the key ingredients to success. Each of the Action Plans encompasses a concrete set of policy goals to be reached by the respective countries. 
Nevertheless, on 22 February 2005, Moldova was the first ex-Soviet state to conclude a fully-fledged Action Plan with the EU, ${ }^{1}$ with a three-year timeframe. Action Plans do not promise anything like EU membership by default, even if ideally implemented. Nevertheless, some of the lessons can be effectively teased out from experience. The Plans aim to provide incentives critical to these countries with which to strengthen political and economic reforms and assimilate new values and standards that could bring them closer to the EU. Considering the pay-offs in having prosperous and democratic neighbours, the EU saw its new policy as a genuine test under which the elites in these countries could address their strategic public issues and vulnerabilities.

Monitoring the results of the last three years is a legitimate measure in which there has been widespread interest on both sides, both the implementing and the assisting parties, i.e. domestic governments and the EU. This article addresses the subjective dimension of the implementation of the Action Plan in Moldova, as well as its lessons and drawbacks, and provides a critical analysis of the feelings that citizens read into EU demands and offers. A survey was carried out during February-April 2008, representing a comprehensive case study on the practical use of the European Neighbourhood Policy in Moldova, which may serve as a magnifying glass with which to assess the energies that it has released and, perhaps, the mood that yet lies ahead. ${ }^{2}$

Experts interviewed within this survey (European or local, governmental or nongovernmental) face difficulties in deciding upon the timeframe as to when the muchdesired accession of Moldova could take place; nevertheless, they stated unanimously that this will imminently occur. It is a historic opportunity which depends on the level of interaction between several different actors and their variable strategies: the domestic evolution of Moldova; the 'domestic' business of the EU; the well-being of the European economy, in terms of how it will impact on and be perceived by its constituent nations; and, last but not least, the degree of effort invested by the Moldovan elites and by the population itself to gain a statute that it deserves.

\section{The views of Moldovan citizens towards the European Union}

\section{The EU is publicly trusted and genuinely attractive to Moldova citizens}

Citizens have a high level of trust in the EU. It seems that the EU is the third most trusted institution at the national level, being outranked only by the Church (the largest in Moldova is the Christian Orthodox Church) and by some of the most popular TV

1 The conclusion was reached at the 7th meeting of the EU-Republic of Moldova Co-operation Council. The European Union was represented by Jean Asselborn, Deputy Prime Minister and Minister of Foreign Affairs of Luxemburg; and Moldova by Vasile Tarlev, acting Prime Minister.

2 The survey was conducted by CBS AXA in February-March 2008, on a stratified bi-staged sample of 1083 people aged more than 18 years old, according to the following stratification criteria: twelve geographic regions, coinciding with territorial administrative units above the district level; type of residential environment (urban-rural); the number of electors in urban localities (two types); and the number in rural ones (two types). The number is representative of the adult population with a maximum error of $+/-3 \%$. 
channels; at the same time, the EU is held much more reliable by ordinary citizens than are the domestic authorities.

Greater confidence in European institutions in terms of the promotion of European integration compared to domestic state institutions

European institutions are also appreciated positively by citizens through the activities being carried out on the long road towards Moldova's integration with the EU, especially when compared with other domestic authorities. Listing the confidence scores reported by the survey, one may certainly remark the level of trust in the EU delegation (61\%), the embassies of EU member states $(58 \%)$ and the country office of the Council of Europe $(58 \%)$. The EU institutions are clearly appreciated positively by a bigger number of citizens than are domestic state institutions such as the government (42\%), the presidency $(41 \%)$ and the parliament $(41 \%)$. It is worth noting that the Christian Orthodox Mitropoly of Basarabia, associated in general with Romania, an EU member state, gained much confidence on the part of the public (59\%).

Figure 1 - Level of confidence in public and private institutions in Moldova, and the institutions which are perceived to do most for the European integration of Moldova

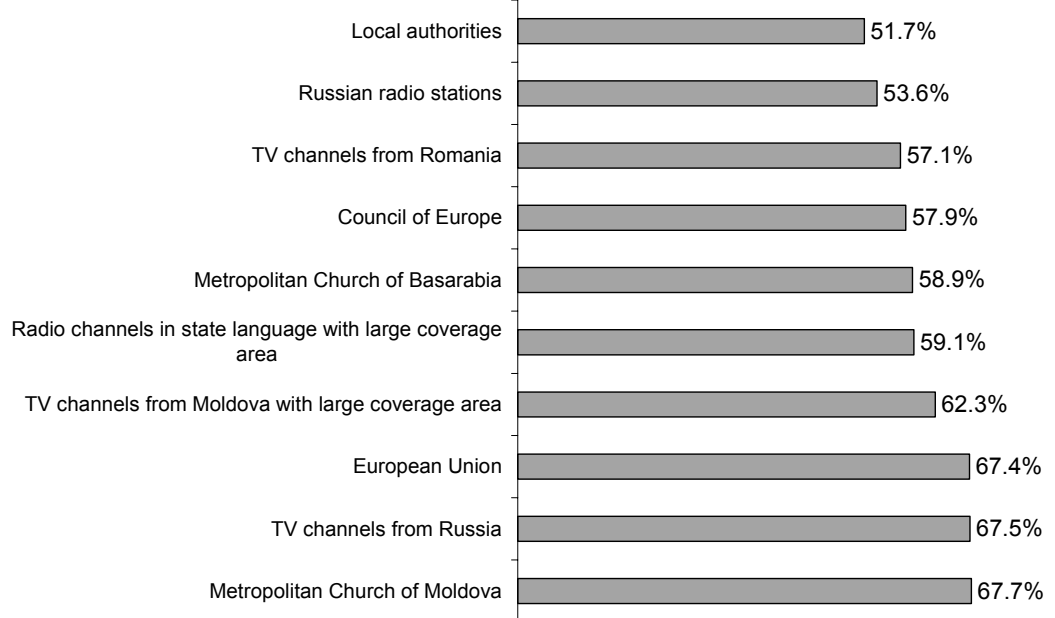






Age and education correlate positively with support for the EU

There is a correlation between age and a positive assessment of the activities of the presidency in the promotion of the European integration of the Republic of Moldova and the implementation of the Moldova-EU Action Plan. The share of young people aged 25-29 who give a positive assessment to these activities is the lowest (14.1\%) while the share of respondents aged 60 and older is much bigger. Responses also vary by area of residency: the activities of the presidency are less appreciated in the central and southern regions of Moldova (respectively $67 \%$ and $75 \%$ deliver a negative assessment).

\section{Most people are interested in the EU and in its plans towards Moldova}

Almost $70 \%$ are interested in European affairs with only $8 \%$ saying they are not interested. Respondents also believe that EU membership would have a positive impact on relations with Romania, an EU member state, and Ukraine, a country which shares a border with the EU. In contrast, EU membership would be less likely to have a positive impact on relations with the US and, more particularly, with Russia. It appears that a general knowledge of the EU as a continental actor is directly bound up with the personal motivations and individual interests of those interviewed. In other words, an instrumental cognition of the EU is considered to be a much more relevant indicator as it describes an action value, directed towards behaviour, actions or a will to know different aspects of European integration. 
Figure 2 - How interested are respondents in Moldova-EU relations and what impact do they think membership would have on relations with other countries?

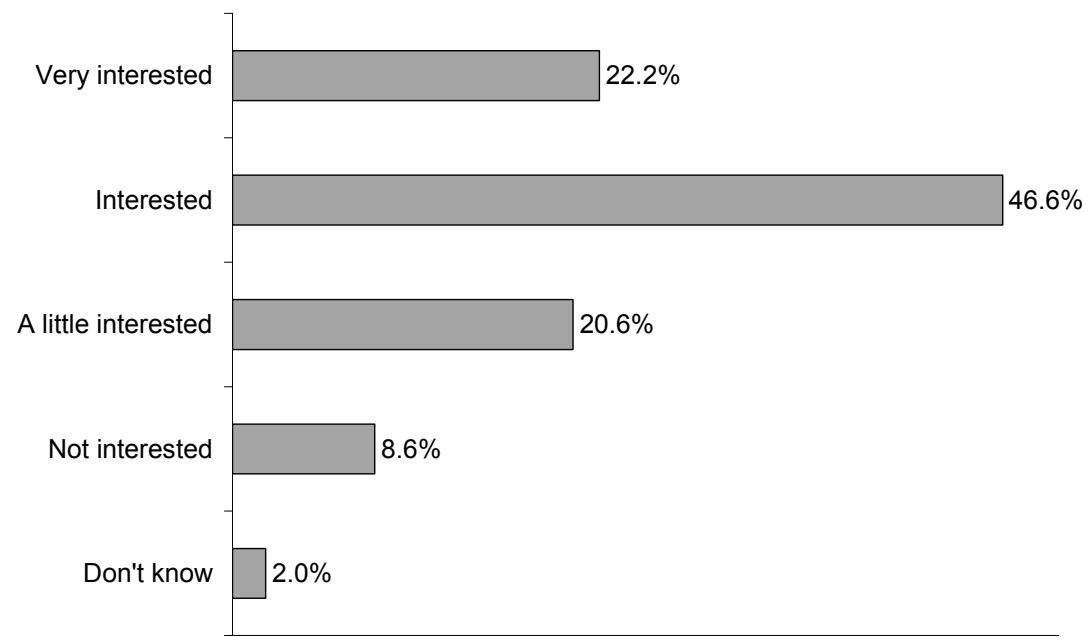

Relations with USA

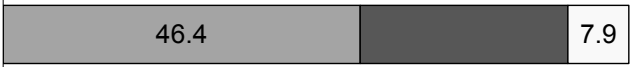

Relations with Russia


$\square$ Positive impact $\square$ No impact $\square$ Negative impact

Romania can help Moldova most in its European integration process

Romania leads the list of states perceived as Moldova's supporters on its path to integration with the EU, with $19.5 \%$, followed by Italy $(12.7 \%)$, France $(11.7 \%)$ and Germany $(10.2 \%)$. Surprisingly, Russia is also among the supporting states, with $10.1 \%$. The paradox of this choice from respondents is apparently connected with the ambiguity and the special role of the northern neighbour in terms of its influence in Moldova. 
In the case of a referendum, Moldova would join the EU

Citizens' attitudes towards the European Union and the possible accession of Moldova to the EU is more than positive. In the case of a referendum, $77 \%$ would certainly vote for the accession of Moldova, compared to the $35 \%$ who would vote for NATO membership. It is worth mentioning here that this knowledge is strongly located within respondents' state of awareness especially about NATO $-88 \%$ of respondents had heard about NATO - but a smaller proportion were as well aware of the EU.

People believe Ukraine and Georgia lead the membership integration race

Asked about the order in which particular stated countries would join the EU, respondents consider that Ukraine and Georgia have the biggest chance, with Moldova in third place, ahead of Armenia and Azerbaijan. The lowest scores show the order of priorities that respondents gave to those with the best chances of joining the European Union.

\section{Figure 3 - Votes for accession to the EU and NATO, and likely order of integration of eastern states in the $\mathrm{EU}$}

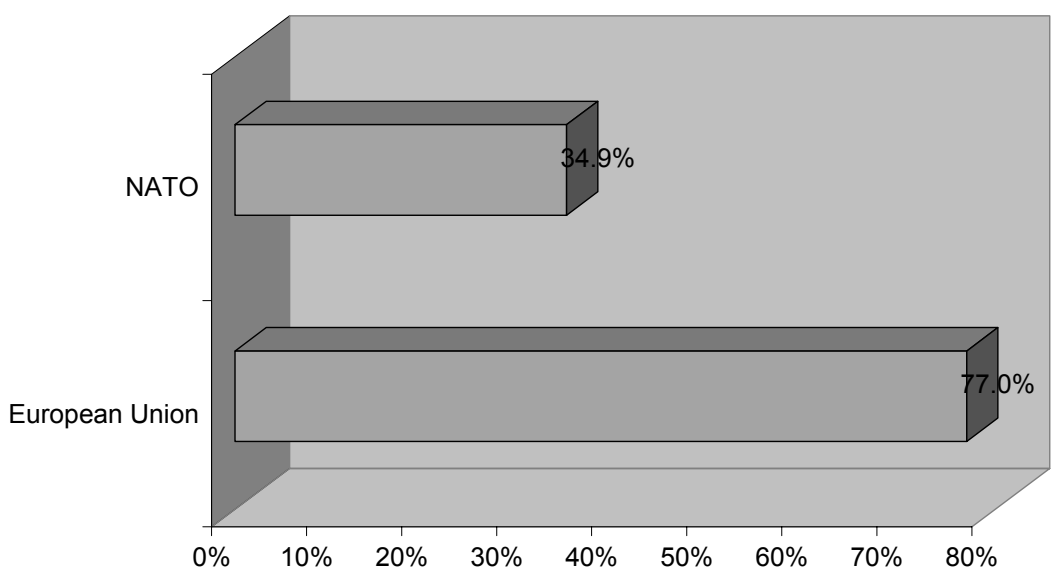




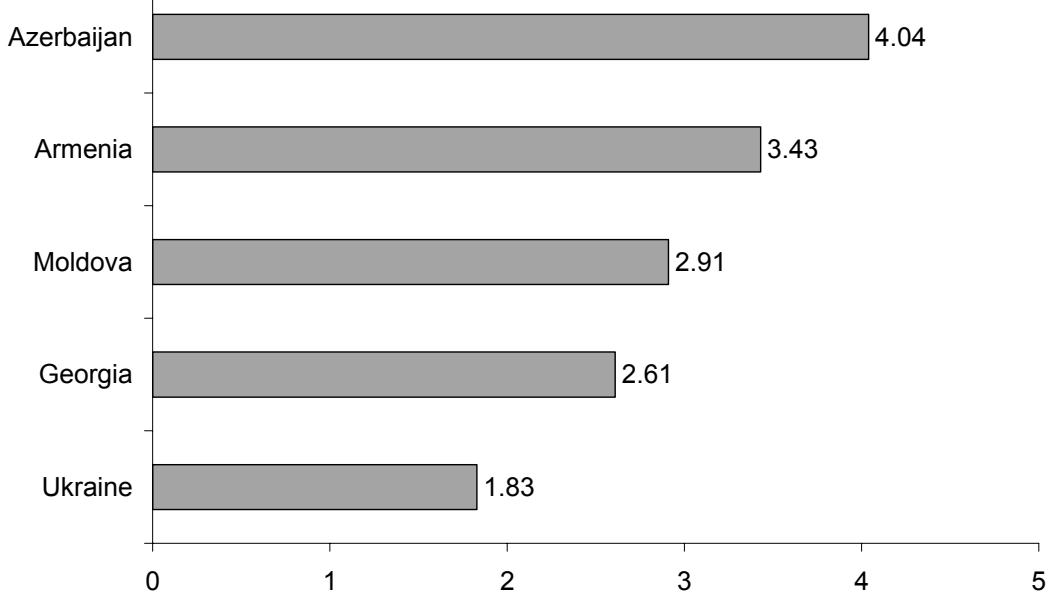

Respondents believe Moldova will join the EU in 10-15 years

Respondents refuse to treat the accession of Moldova to the EU in abstract terms, i.e. by diplomatically avoiding saying something on the issue. Respondents want to speak positively on accession and the most optimistic see this taking place within five years $(22.8 \%)$. The largest proportion, however, consider that the next 10-15 years is the most suitable time for this event to take place (35.4\%), while $10.6 \%$ believe $15-20$ years. Just less than nine per cent consider that the accession of Moldova to the EU would not take place in the next twenty years while around seven per cent assert that Moldova will never join the EU.

Moldova will only benefit from accession

Nearly one-half of respondents ( $48.7 \%$ ) consider that Moldova's accession to the EU would provide more advantages than disadvantages; $23.5 \%$ consider that accession would provide only advantages; and $11.1 \%$ say that there will be neither advantages nor disadvantages. About three-quarters of respondents (73.3\%) assessed Moldova's eventual accession to the EU as positive, compared to $14.3 \%$ who had no opinion on that (i.e. whether it was good or bad). Some $41.2 \%$ of respondents do not plan to leave the country after accession, while $39.2 \%$ would plan to do so for a short period only. Just $13.3 \%$ said that they would leave Moldova for good in this eventuality. 
Figure 4 - When do citizens think Moldova will join the EU and what are their perceptions of the advantages and disadvantages of accession?
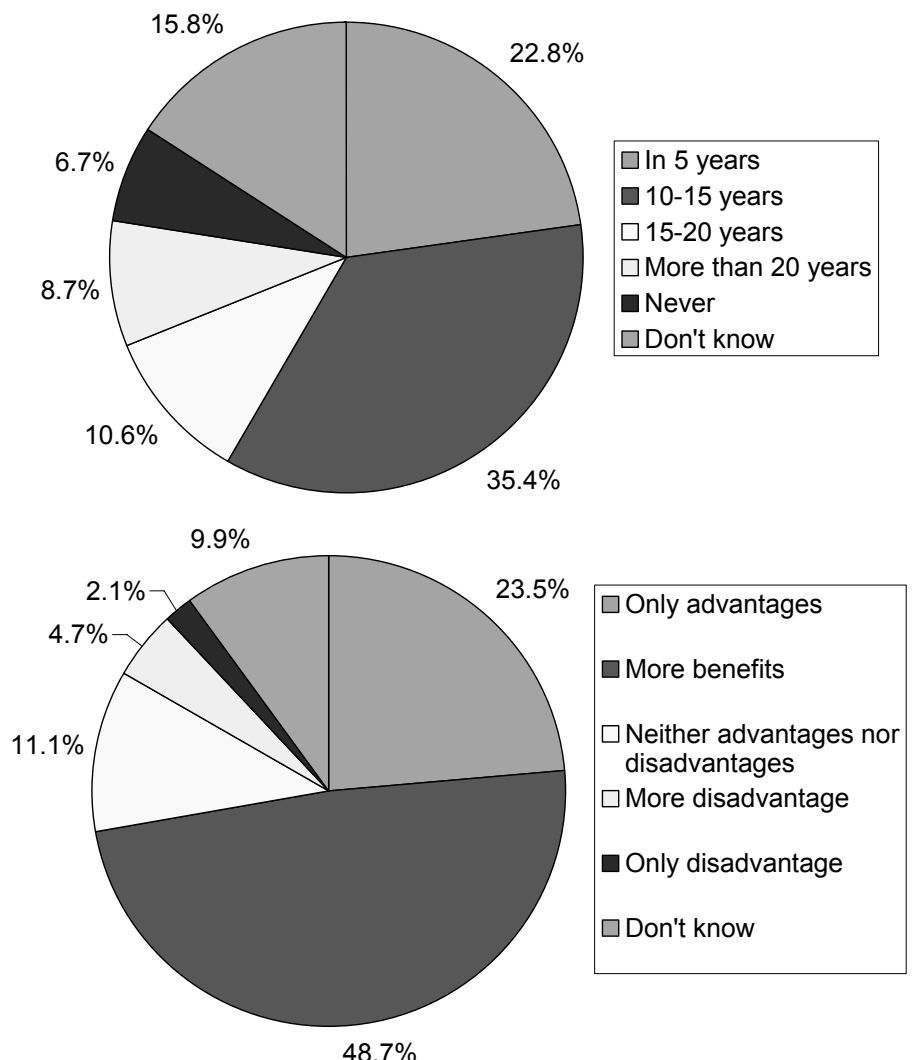

Public opinion is critical of Moldova's image within the EU, but the EU records a better image in Moldova

Clearly, the EU is perceived very positively by the greater part of the population in Moldova. Public opinion is critical of Moldova's image within the EU; at the same time, it has further demands of the national government: $56 \%$ of respondents see the EU as having a good image in Moldova, but only $35 \%$ see that Moldova's image is good in the EU. Overall, however, respondents believe that Moldova is not negatively appreciated abroad, which has a strong influence on their perceptions towards European integration as a whole: people would have shown resistance to integration if they believed that the EU represented a hostile environment or a threat to community identity. Just $14 \%$ of respondents believe the image Moldova has is very bad while $13 \%$ consider it to be bad. 
Figure 5 - What do respondents think is the image of Moldova in the EU and of the EU in Moldova?

\section{i. What image does Moldova have in EU?}

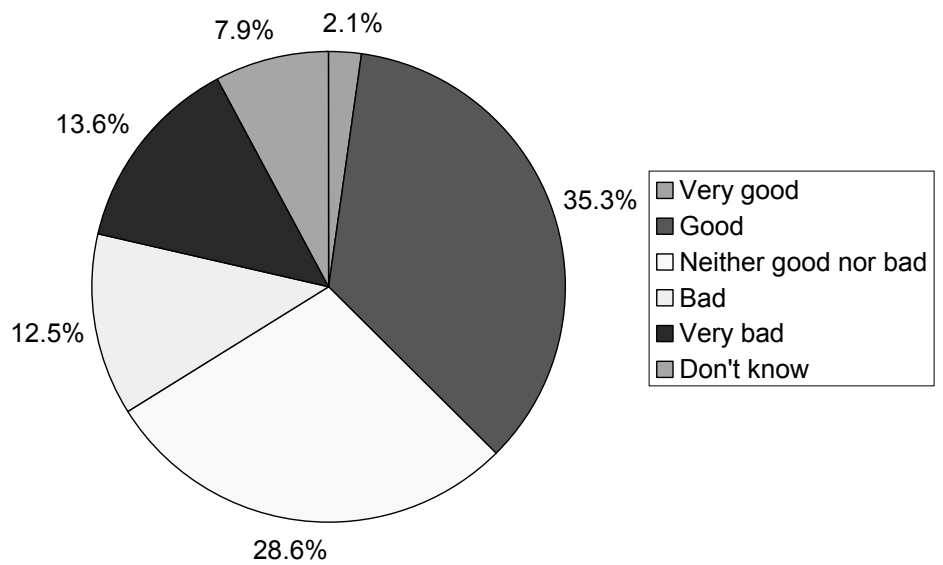

\section{ii. What image does EU have in Moldova?}

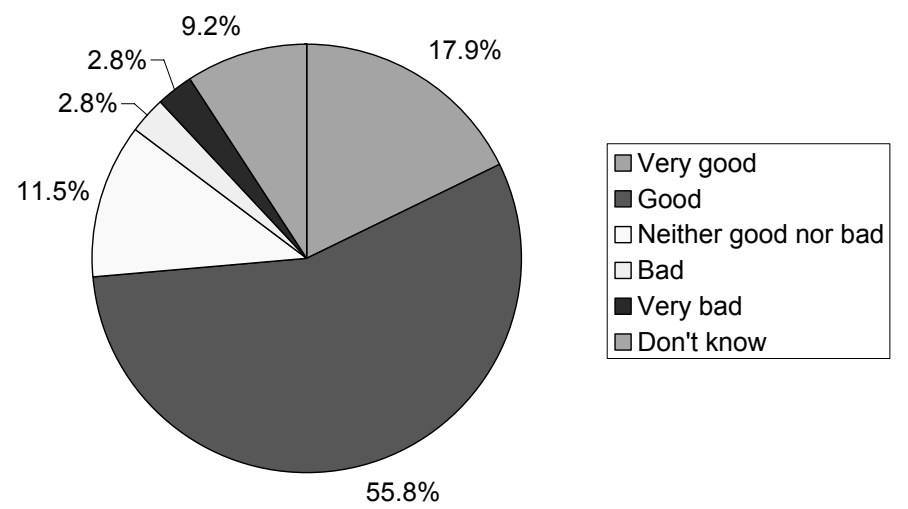

Moldovan citizens think the EU means 'economic prosperity'; NATO is purely 'military'; and CIS is 'just Russia'

The level of trust exhibited towards various organisations has always created a hook for political participation and expected behaviour both at the individual and at the national-community level. It is, therefore, essential to assess the expected benefits and costs in such organisations as rated by respondents. The EU is associated primarily with 'economic prosperity' (16.4\%); 'peace' $(15.3 \%)$; 'freedom to travel, study and work in the EU' (14.3\%); 'larger number of jobs' (11.6\%)'; 'material welfare' $(9.9 \%)$; etc. 
On its account, NATO is perceived in military terms despite the Alliance being defined today as a political-military alliance. NATO is simultaneously associated with being a 'political power' $(9.2 \%)$ and with 'peace' $(11.5 \%)$ which is an apparent paradox. Citizens also associate NATO with 'state security' $(6.3 \%)$ and 'democracy' $(5.4 \%)$. Certainly, the political and the economic dimensions of the Alliance are less well-known in Moldova.

The CIS is associated most of all with the Russian Federation (18.7\%), while a smaller number associate it with 'peace' $(15.3 \%)$ and with 'economic prosperity' $(16.4 \%)$. It is worth mentioning that the CIS is perceived by citizens as an economic solution for Moldova despite or, mainly, because it is associated mostly with the Russian Federation.

\section{Figure 6 - With what are the EU, NATO and the CIS associated?}

\section{i. EU}

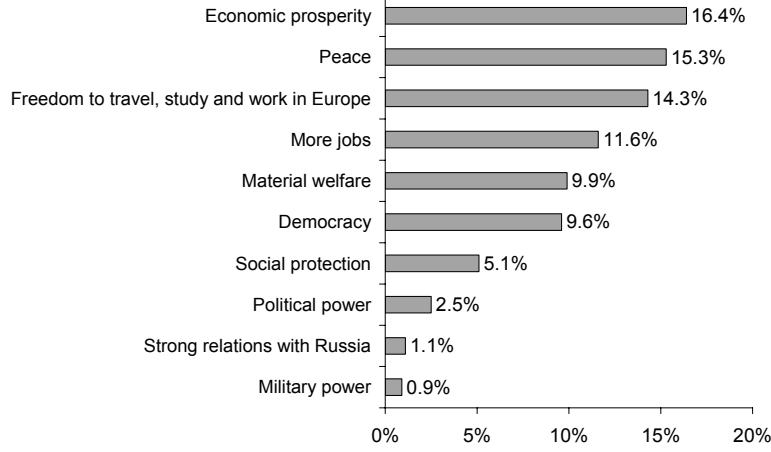

\section{ii. NATO}

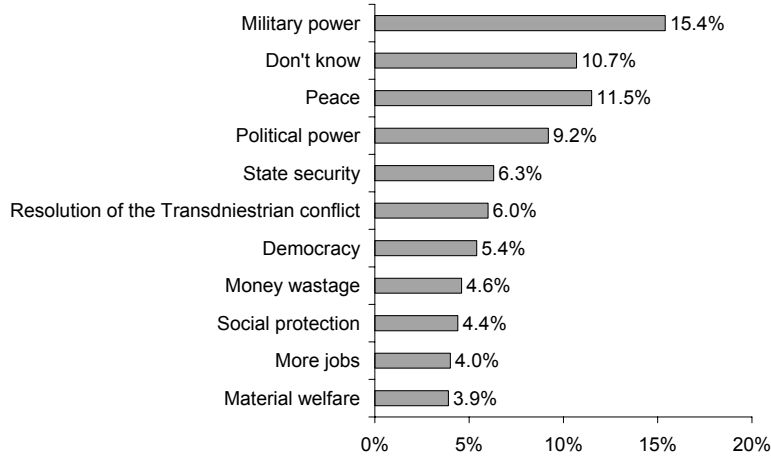




\section{iii. CIS}

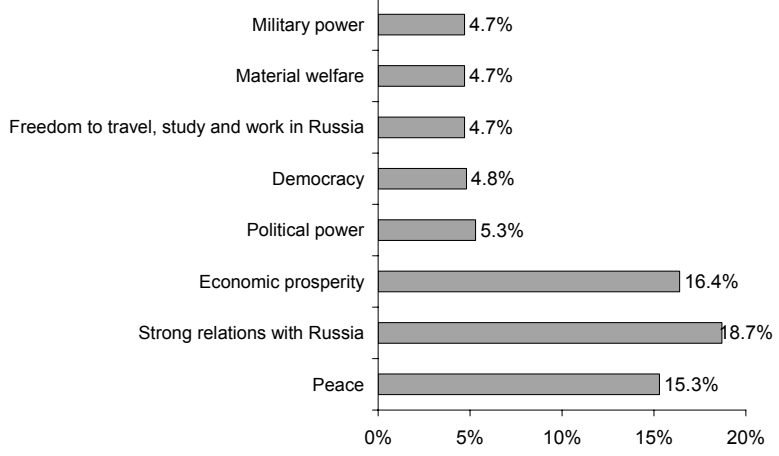

How detailed is the knowledge of the EU amongst Moldovans?

The research results show that, evidently, a large percentage of Moldovans know what the European Union and its policies, including the Action Plan, mean, but they have only a general, vague understanding of the subject. $93.6 \%$ of respondents have heard about the European Union; but $77.7 \%$ assert they know what the European Union is. Those having some general knowledge, even if it is formed, in particular, by the media, are less numerous. This could be explained by the huge influence of Russian TV channels in Moldova. The number of people having in-depth knowledge about European integration and, especially, about relations between Moldova and the European Union is minimal.

\section{Knowledge about European Neighbourhood Policy and the Action Plan}

More specifically, only one-third of the population (36.6\%) is aware that an EU-Moldova Action Plan exists, while nearly one-half (46.2\%) claim that they know what the European Neighbourhood Policy is. The share of the population knowing of the existence of the Action Plan appears relatively small but, on the other hand, even the existence of one-third of informed respondents represents an important statistic, given the complexity of the goals formulated by the Action Plan. In addition, Moldovan public opinion usually shows little interest in the strategies and action plans of the Moldovan authorities. 
Figure 7 - Have you heard about the European Neighbourhood Policy? And is information about the EU sufficient in Moldova?

i. Have you heard about the European Neighbourhood Policy?

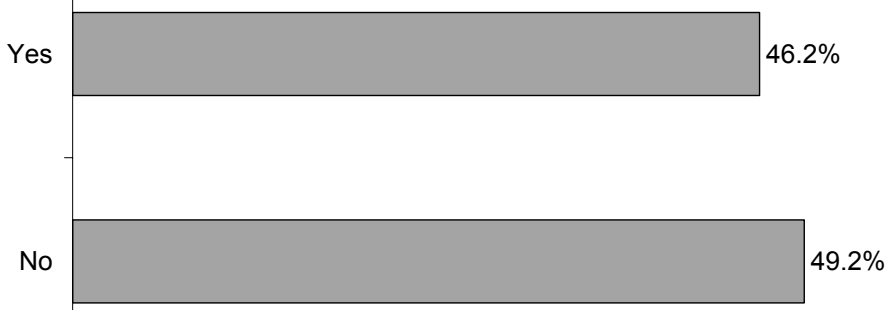

Don't know $\quad 4.5 \%$

ii. Is information about the EU sufficient?

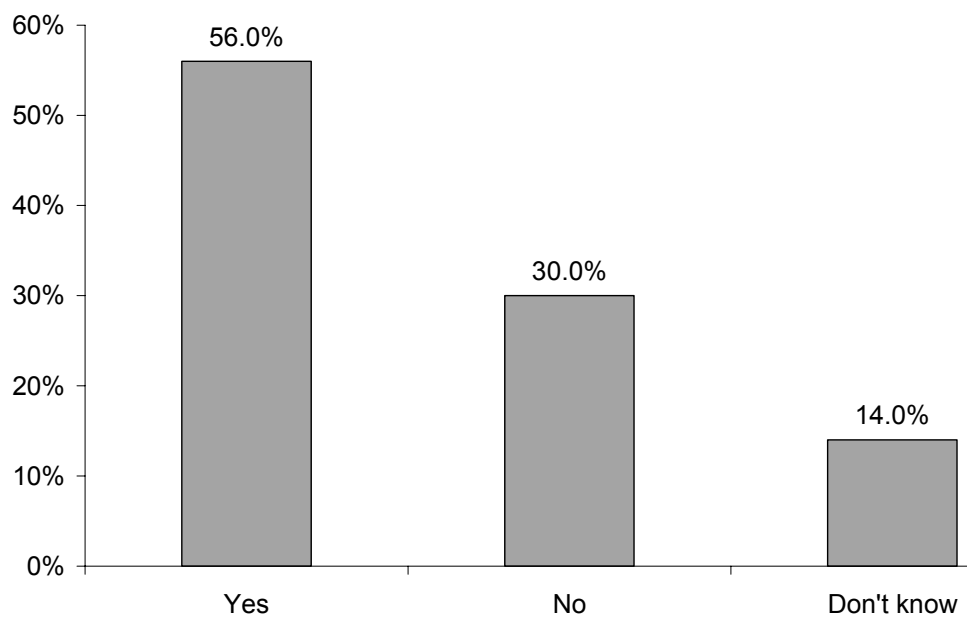

People choose TV and radio as most preferred sources of information

When given alternatives, citizens decide that TV and radio are the primary sources of information. TV and radio stations are the most important and influential source of information about the implementation of the Action Plan $29.5 \%$ and $18.7 \%$ respec- 
tively). The written media comes last (5.1\%), at a significant distance after electronic media, communication with neighbours and relatives, and even the internet. Citizens' preferences for information distributed by means of the electronic mass media, as well as interest in cognitive/analytical publications and brochures intended for public information $(8.0 \%$ and $8.3 \%$ ) are worthy of mention. Clearly, citizens' preferences are still continuing to be crystallised and new ways of the dissemination of information are sufficiently appreciated by information consumers.

Figure 8 - From where do Moldovans find out about the Action Plan and from where do they find out about the EU?

\section{i. Action Plan}

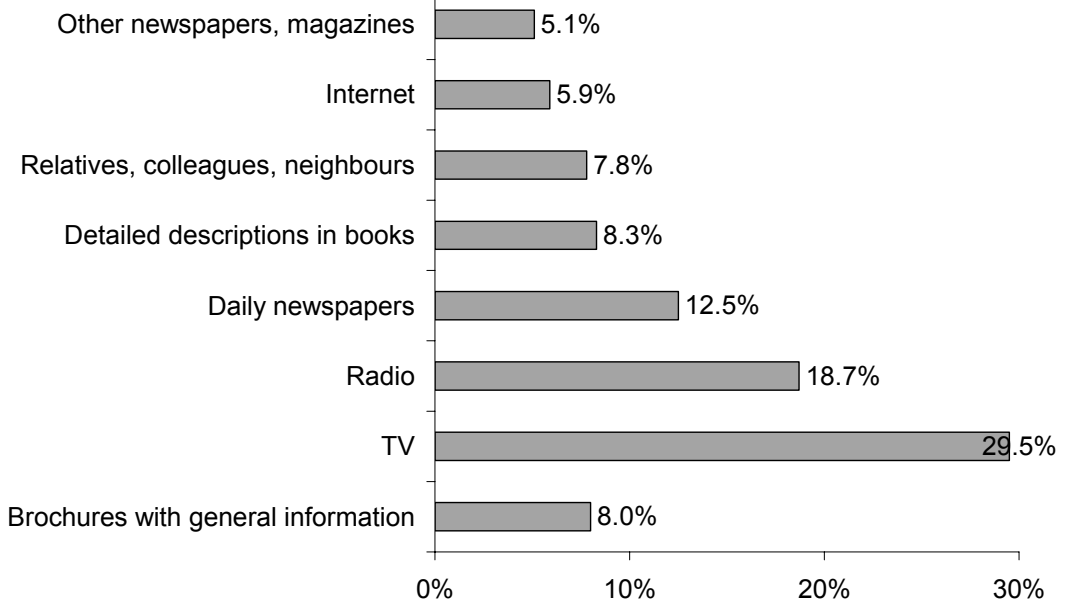




\section{ii. Information about EU}



\section{Profile of citizens who support the EU in Moldova}

The sociological profile of the typical EU supporter can be outlined as follows: a young person aged 18-29, with higher or incomplete higher education; Moldovan/Romanian or Bulgarian; and usually having a family member who has migrated to an EU country for short- or long-term employment. Moldova is one of the most intensive emigration countries of the world. Official statistics shows that almost 450000 Moldova citizens have recently fled abroad for work, but unofficial reports assess the actual number of migrants as almost 900000 (half of whom would be located in western Europe).

Strong confidence in the EU is seen as putting imperious pressure on the political elites to pursue a strong pro-EU course in Moldova. It seems, however, that the positive image of the EU is not supported by appropriate knowledge of the 'European business': almost $56 \%$ of respondents stated that they have as yet insufficient information about EU, despite the variety of information channels to which they have access, while just $3 \%$ are satisfied with the quality of information that they receive. Usually, citizens obtain information about the EU primarily from electronic mass media (TV channels from Moldova, Russia and Romania being quoted as the main communications tools). Speaking of citizens' information needs about the implementation of the Action Plan, citizens prefer to watch TV channels from Moldova with a large area of coverage, newspapers and magazines in the state language and TV from Romania. A small number of people, amounting to $3.2 \%$, use the internet to find out about the progress of the Action Plan. In fact, citizens' preferences for information differ little from the current sources used by them. 
Figure 9 - Where do citizens get their information and how would they like to be informed?

\section{i. Sources of information}

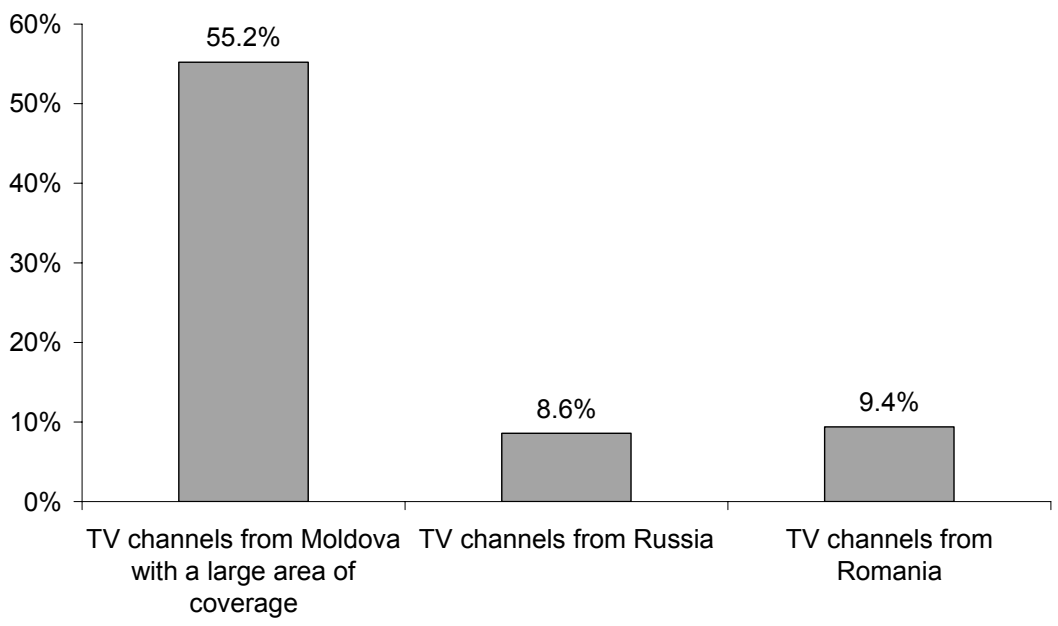

\section{ii. Preference for information sources}

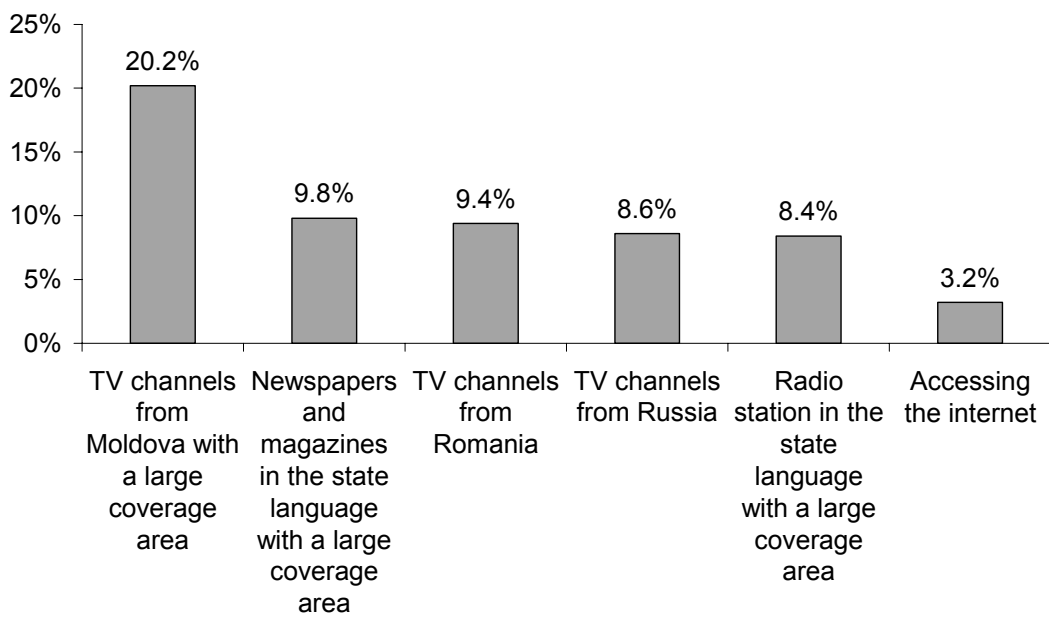

Television contributes most of all the European integration of Moldova

Indeed, TV channels are thought to contribute most of all to Moldova's European integration process $(17.5 \%)$, followed by the main public institutions from Moldova: the government $(14.1 \%)$; the parliament $(12.1 \%)$; and the presidency $(10.8 \%)$. Citizens 
evaluate quite modestly the contribution of several institutions which are less directly connected with the promotion of the goals of European integration, such as: the political parties $(7.1 \%)$; NGOs $(5.5 \%)$; the private sector $(3.2 \%)$; and academic staff $(2.6 \%)$. The highest satisfaction with the way the Moldovan media covers the European integration process and the issue of the implementation of the Action Plan is attributed actually to radio stations, despite the main sources of information about the EU being, as we have seen, TV channels.

Figure 10 - Which institutions contribute most to Moldova's European integration process, and how does the mass media in the country cover it?

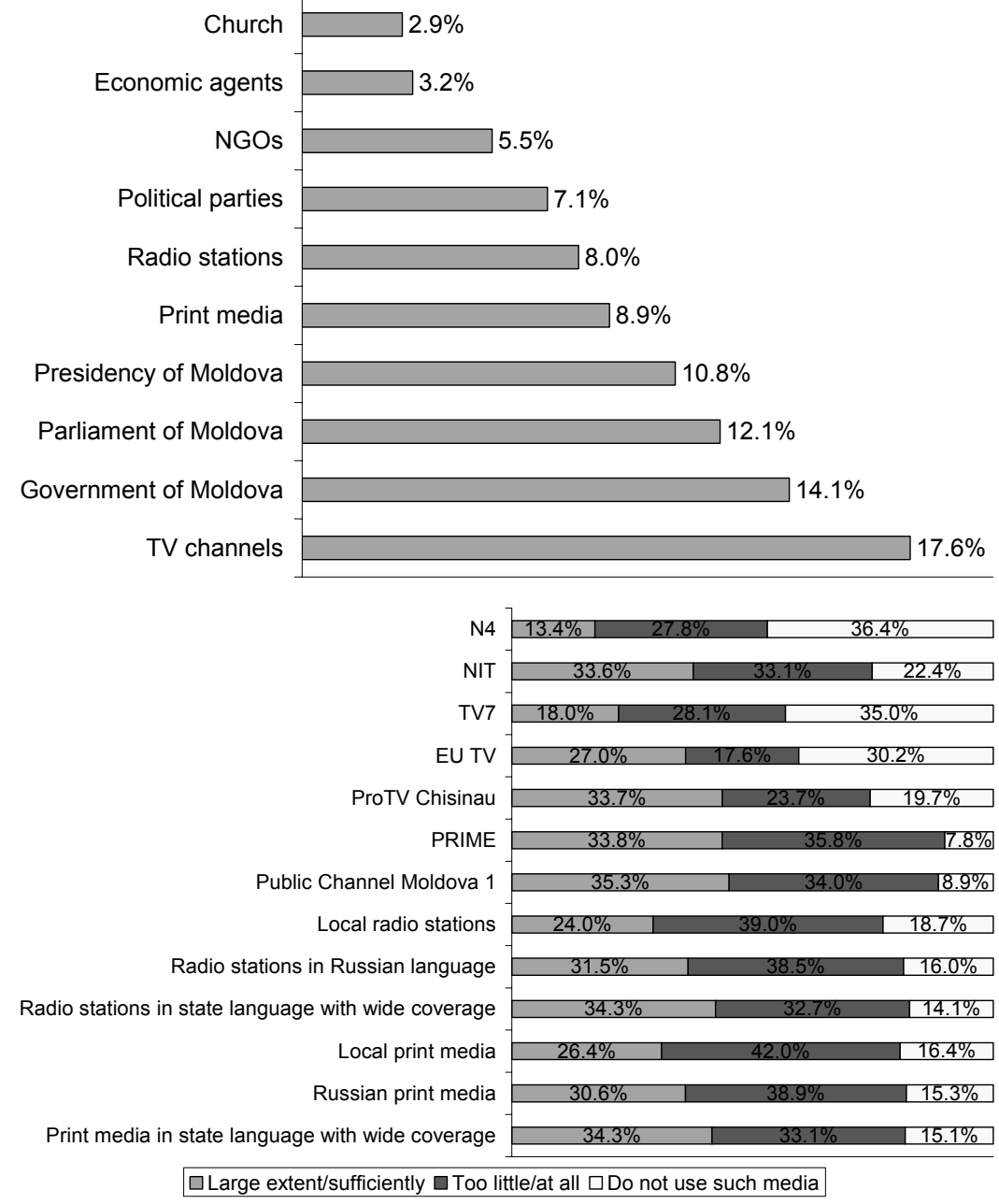


The information channels about the EU institutions are apparently diverse. However, at the same time, most respondents do not look for information about the EU, so it is difficult to judge the quality of such channels.

\section{Impact of EU integration on the social standing of citizens in Moldova}

Even if respondents are not sufficiently well-informed about the European Neighbourhood Policy, the Action Plan and relations between Moldova and the EU, most of them are aware that the quality of their life depends on the implementation of these strategic documents. Nearly $89 \%$ think that implementation of the Action Plan is important or very important; while just $5 \%$ consider it to be unimportant.

People show dissatisfaction with the implementation of the Action Plan

The importance of the implementation of the Action Plan is almost unanimously recognised, and there are no considerable discrepancies as regards its effects, but the direct assessment of some chapters of the Action Plan reveals a critical attitude on the part of a number of respondents. The public is aware of the need for the implementation of the Action Plan, but it is not sure that the government is doing the right things to achieve this goal, or that it will do so in the future.

Figure 11 - Correlation between the implementation of the Action Plan and improvements in quality of life, and respondents' assessment of the implementation of political dialogue and democratic reforms

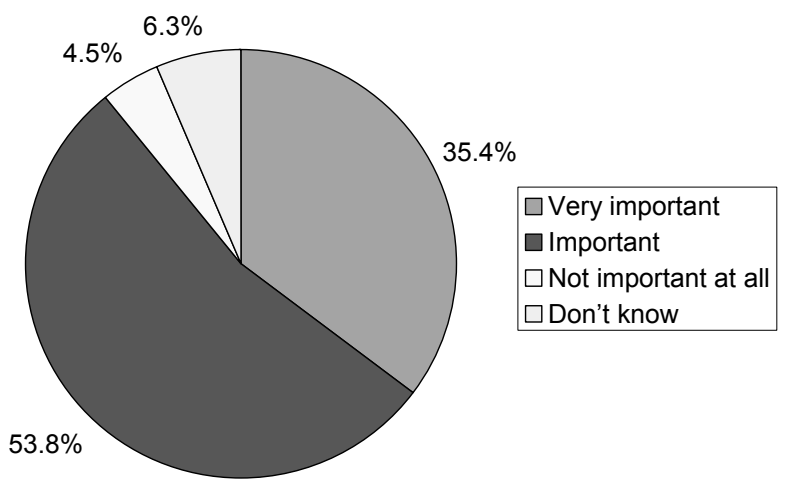




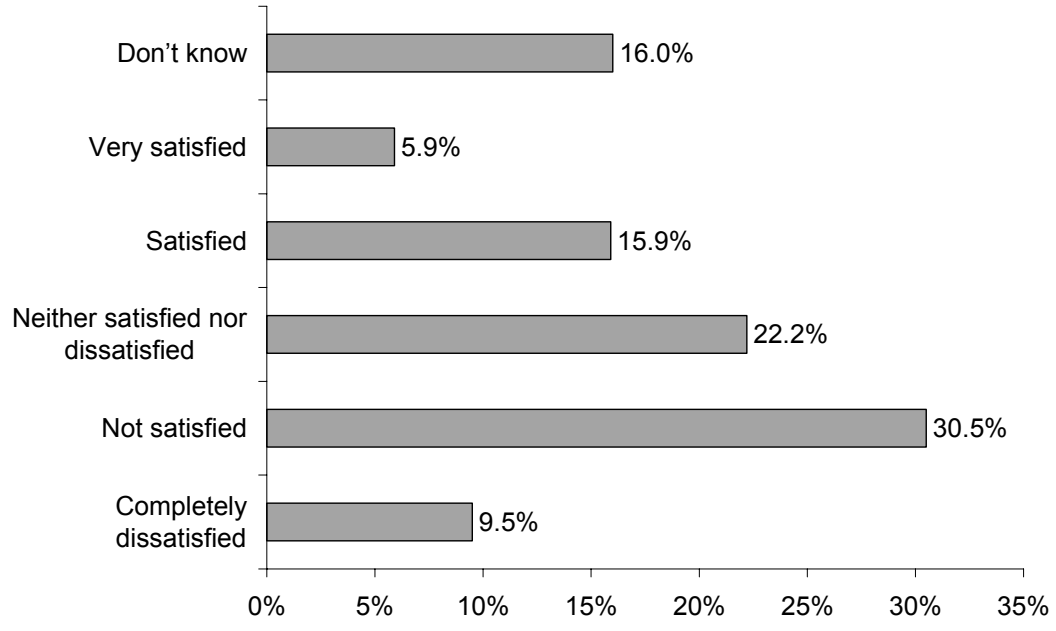

Wrong or even partial information about the EU is a concern

The results of the survey identified plenty of imprecise information about the EU's main policy towards its neighbours. Most of the respondents were inclined to believe that the Action Plan was something granted exclusively to Moldova and that it heralded the prospects of accession to EU later in 2008. Several efforts have been made in the last few years to inform citizens about the EU and Moldova's efforts to adjust its policies to the EU's standards, but the population knows very little about what the struggle for European integration really means, what the costs are and what is the path which has to be followed.

Even so, simple statements regarding awareness of the Action Plan do not provide sufficient statistical relevance. Respondents often claim awareness of some issues or documents which are otherwise totally unknown as a result of making an effort towards compliance, or a conformist positioning vis-à-vis the group 'under consideration', aiming at gaining greater respect from those who are assessing the answers. Following this line of logic, we sought to cross-check the degree of effective awareness of the Action Plan by means of some statements with relative validity, through which we asked respondents to say something about their level of awareness.

Sixty three per cent of the citizens of Moldova said that the Action Plan is a preaccession agreement with the EU, while $51.3 \%$ saw no practical use for it. Almost $40 \%$ of citizens expected that Moldova would become an EU member in 2008 against $47.3 \%$ who were not so sure about that. Almost $48 \%$ of respondents attributed the main role in the implementation of the Action Plan to the incumbent President, Vladimir Voronin, while $57.2 \%$ said this was within the competence of the Ministry of Foreign Affairs. 
The lack of political will and scarce financial resources are slowing down European integration

The survey identified considerable deficiencies and gaps between the declared reforms and their practical effects as perceived by the public. The instruments of European politics in Moldova are assessed by the largest part of Moldovan citizens as only partially satisfactory. The public would, in turn, favour resolute steps to change the functioning of the public sector so as to have rejuvenated and skilled civil servants, working on behalf of the public interest.

Thus far, people feel that the implementation of the Action Plan is slow, ambiguous and declarative only. The most important deficiencies in assessing the Action Plan are largely: the lack of political will to make an effective European commitment (27.3\%); the scarce financial resources allocated to it $(21 \%)$; poor administrative capacities $(11.9 \%)$; and the volatility of the level of responsibility assumed by the political class $(10.7 \%)$. Public consultation on the main objectives of the reforms are significantly restricted by the 'old-business' culture of the state bureaucracy which inclines to dedicate less effort than promised.

The obstacles, as perceived by the population, which are stopping Moldova's European integration are the corruption of the authorities $(23.3 \%)$, political instability $(11.8 \%)$, the unsettled Transnistrian conflict $(9.4 \%)$ and the lack of political will $(7.2 \%)$.

The lack of political will efficiently to realise the tasks of the European integration of the Republic of Moldova is mostly felt amongst the population from Chişinau, the capital of Moldova (37.3\%). Citizens who think that the lack of political will is the main impediment to European integration are usually well-educated, while people with little education usually focus on the lack of financial resources. Economic competitiveness and investments are treated as the derivatives of 'administrative capacity' and political will. 
Figure 12 - What does Moldova lack concerning implementation of the Action Plan? What correlation is there between opinion on the lack of political will and geographic location?

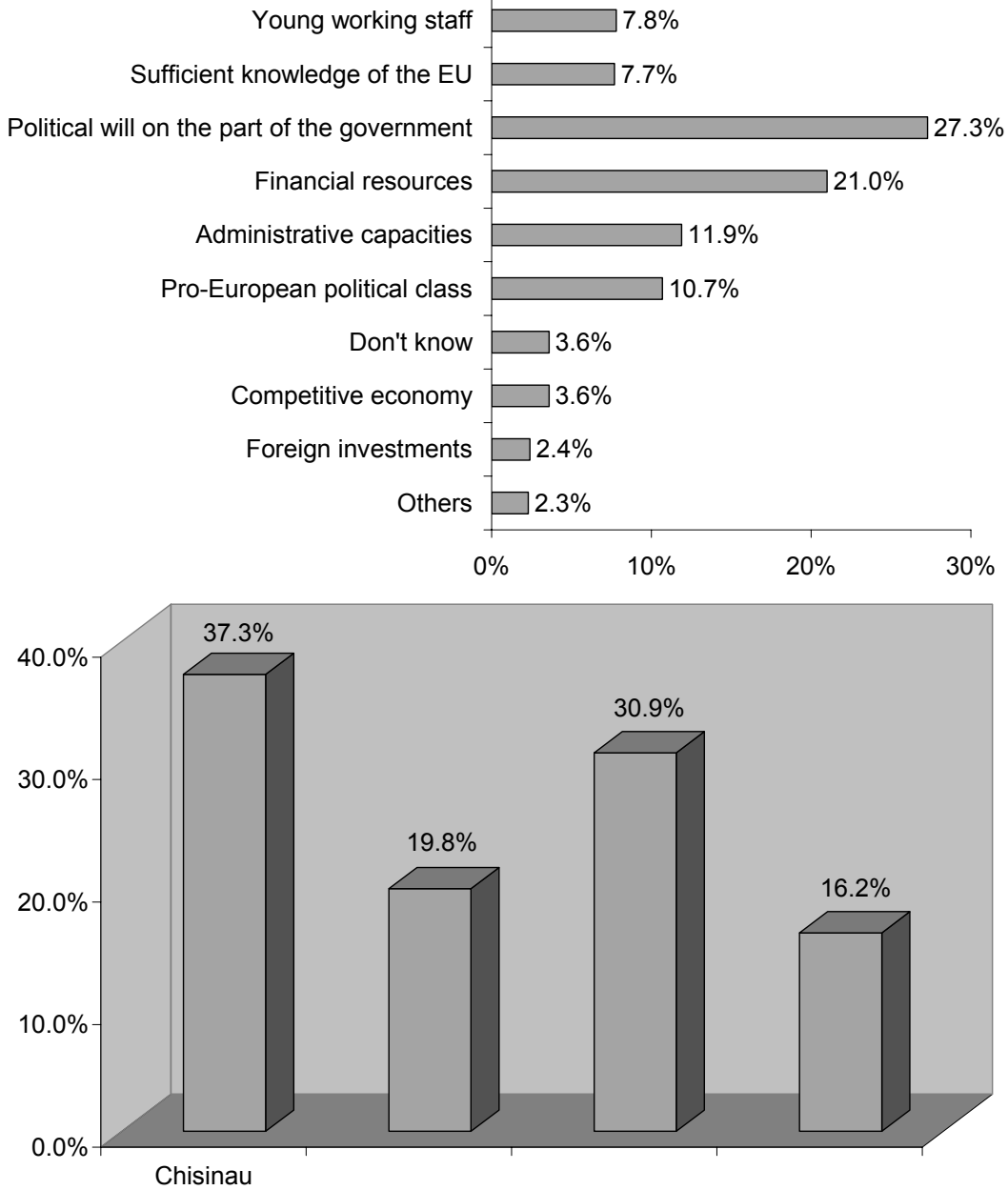

Respondents do not feel any changes

Survey respondents did not feel that there had been many essential changes in their individual lives. During the three years of the implementation of the Action Plan, the number of jobs had not increased (75.3\%); there was no visible decrease in poverty (75.1\%); durable local development did not exist (70.9\%); and there was no considerable improvement in addressing the Transnistrian secessionist conflict (68\%). Overall, the economy had not become more viable (64.9\%); the use of public money had 
not become more transparent $(63.5 \%)$; while human rights were observed to a no greater extent $(63 \%)$. Less than one-half of the population believes that elections were fair and free $(43.2 \%)$, that the press had become more independent $(40.7 \%)$ or that the education system was closer to European standards (40.7\%).

Economic development and accountability are the priorities

Nevertheless, and somewhat in contrast to the lessons of experience with the Action Plan, over four-fifths of the population $(82.4 \%)$ think that integration in the EU will have a positive economic impact on Moldova: $81.4 \%$ think there will be greater possibilities for the free circulation of citizens and goods; $80.3 \%$ expect the growth of foreign investment; $79.9 \%$ expect an increase in the number of jobs; and $78 \%$ expect better incomes, in terms both of salaries and pensions. Another $71.3 \%$ would expect as an outcome the development and modernisation of the agricultural sector.

Meanwhile, the domestic priorities of the government, according to the survey, should be economic growth $(22.2 \%)$, fighting corruption $(19.7 \%)$, the resolution of the Transnistrian conflict $(12.1 \%)$ and combating the phenomenon of illegal migration $(7.3 \%)$.

Figure 13 - Assessment of government efforts for the resolution of the Transnistrian conflict. Which issues should be the government's policy priorities?

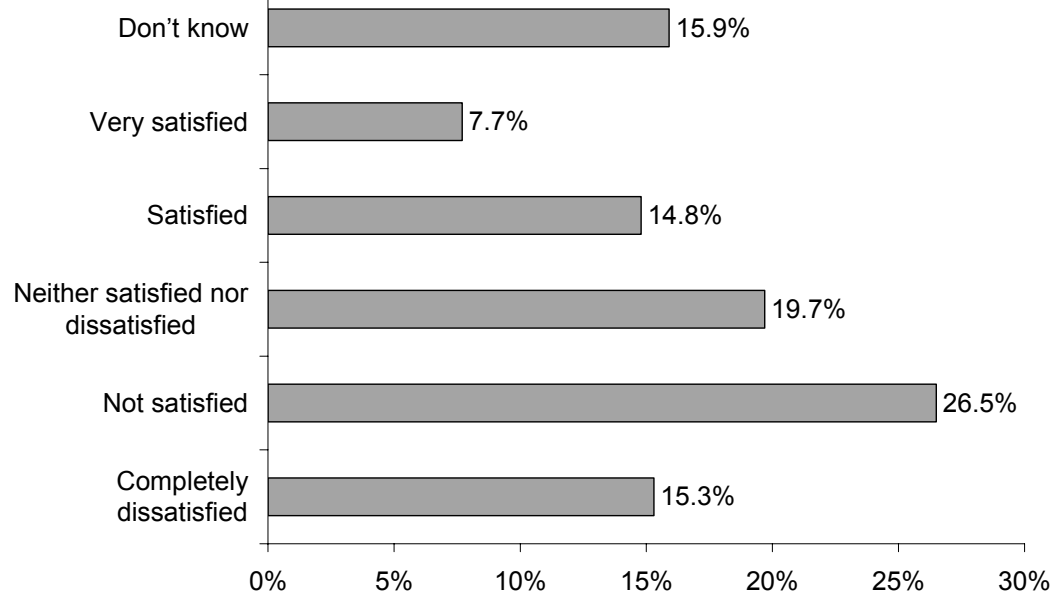




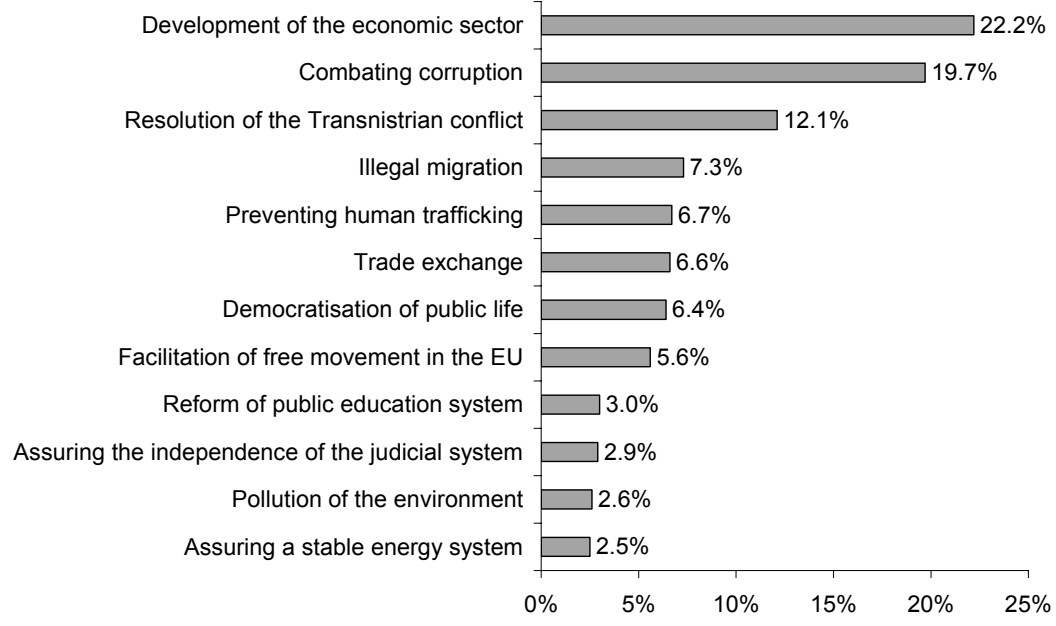

What homework does Moldova need to do to advance its prospects for EU integration?

The employment of a young and competent administration (79.9\%), establishing the rule of law and respect for European values (79\%); having a good relationship with Romania (74.3\%); securing the accountability of government (73.9\%); developing partnerships with other European countries for education opportunities (69.2\%); having a good relationship with Ukraine $(67.5 \%)$; replacing the current political elites $(64.1 \%)$ and European education $(63.3 \%)$ - all these issues are the most common challenges that Moldova needs to face in order to advance towards EU integration, according to its citizens.

\section{Critical points and setbacks}

The most important aspect which needs to be improved is the effective application of the adopted laws and of the mechanisms of their implementation. Referring specifically to the path of implementation of the Action Plan, experts outline the aspects which need to be changed; in this way, the Action Plan may be encompassed by the central authorities as a list of activities which must be dealt with, without being internalised and without highlighting the priorities, depending on the results which must be obtained in this area.

Any understanding by civil servants or by the heads of departments of the general framework is not evident; issues are not covered from the wider perspective. In illustration, we can refer to the way in which the Audiovisual Law was implemented: this was adopted as one of the requirements of the EU - but not in the way it is currently implemented.

There have, however, been some changes in the field of human rights, progress here referring to attempts made to determine the large number of cases lost at the European Court of Human Rights, given that this has been ignored so far. 
The lack of political will to make particular necessary changes is another impediment pointed out by European experts. An indicator of this is the manner of distribution of the state budget, which does not cover the priorities formulated by the authorities of the country. Thus, a pro-European orientation and an adjustment to European standards do not cover the way in which the budget is distributed. Together with the political impediments referred to previously, a series of technical obstacles may also be perceived. These refer, firstly, to the deficit in administrative capacities, which include low salaries and a poor distribution of resources (an example is the significant difference between the number of civil servants in different ministries and agencies, which does not cover the priorities of the authorities, as well as the lack of skilled human resources and of a coherent strategy to attract young professionals who want to work in public institutions).

It is worth mentioning that the lack of administrative capacities is confirmed, in most cases, as an argument behind the lack of the political will to carry out certain activities, including the following:

- improvement of the business environment, in which some improvements in general have been recorded although some decisions, somehow abstracted from this context, continue to block its development

- no specific actions have been carried out concerning the section referring to 'state aid' stipulated in the Action Plan

- at the same time, the position concerning money laundering has not improved; on the contrary, this has been worsened by initiatives in the legalisation of capital which were established last year.

We should mention in this context a few 'cross-cutting issues' which do not refer to any chapter of the Action Plan but which do affect the situation as a whole, including the adoption of laws which have not been sent for comment to the Council of Europe, referring to aspects which violate human rights or which cover European citizens, etc.

Certainly, the authorities of the Republic of Moldova must be ready to prepare the grounds for institutional accession whenever this is accepted by the European Commission. But, invoking in vain 'accession without Europeanisation' will certainly bar the access of Moldova to any foreseeable accession process. The 'neighbour statute' is rather less important as regards the attention of the general public, but considerable efforts do need to be directed towards the creation of genuine and credible administrative capacity with which the 'real' agenda of accession can be addressed: the rule of law; a competitive economy; democratic and effective, good governance; strong regional governments; European-minded universities and a European-minded general public. Moldova needs to leave aside its various old-fashioned 'tribalistic' or 'gerontocratic' excuses related to our 'special way' of development - real investment does need to be made in the reconstruction of the civil service; the depoliticisation of the state apparatus; the creation of an independent judiciary; and the establishment of freedom of expression.

The acceptance of the conditions 'issued' by the European institutions within the Action Plan and the perception of the changes which need to be made are positive and necessary. On the whole, European experts consider that the biggest amount of progress has been recorded at the legislative level - the chapter concerning the adoption of laws, 
despite the several issues that remain in the process of their implementation. In this context, the adoption by the Republic of Moldova of the different international conventions which it has promised to follow is considered to be of public benefit. What is still to be done in this context is to assure the efficient implementation of these items. A separate role is considered to be played here by the parliament, which focuses mainly on the monitoring of the sufficiency of the application of the adopted laws and items.

There are also actions the results of which are planned to be visible within a few years. This category includes the creation of institutions such as the National Justice Institute and the Agency for the Protection of Competition. Activities connected with the consolidation of the borders of Moldova with the European Union, and mainly the EU's Border Assistance Mission to Moldova and Ukraine, are considered to be successful, while the activity of customs services is perceived to be more efficient and of quality.

The following specific recommendations were provided at the end of the research study by experts selected for their individual knowledge of European integration topics in Moldova:

1. the authorities of the central government must take effective measures to stop the exodus of the labour force to the east, because such destinations abroad cause many indirect consequences for the family left behind and do not generate pro-European attitudes or behaviour; this denotes a need for more persuasive policies towards improving the business environment in the Republic of Moldova, as well as a focus on attracting western investment in the economy of Moldova

2. a favourable framework for improved neighbourly relations with Romania and Ukraine, which are 'natural allies' in the effort towards promoting the interests of the country in view of possible accession to the European Union, needs to be established. Romania continues to remain the European partner of the Republic of Moldova and one that cannot be ignored in Chişinau's march towards integration. The development of better relations with the neighbours must serve as specific objectives of the 'European path', especially in terms of the assimilation of positive practices, the extension of institutional connections and the creation of common infrastructure projects with both Romania and Ukraine for the sake of the modernisation of the country

3. some major priorities exist for assuring dynamic stability and national security, starting from the reform of the security structures of the Republic of Moldova: the Ministry of Home Affairs; ISS; army; and the local police

4. the national framework for the information and public education of the citizens of the Republic of Moldova, in the context of the goals, institutions and targets of European integration, needs to be improved so that the population becomes a natural ally of government agents, carrying specific responsibilities in the adoption, assimilation and application of EU norms and standards

5. there is a need for the categorical and compelling promotion of public service reform, the reform of central government and administrative decentralisation by means of the stimulation of individual competence and of skilled personnel. The selection of staff must coincide with the goal: the promotion of people who have the knowledge and the capacity for understanding what the public interest means 
6. there is scope for the essential modification of the diplomatic service of the Republic of Moldova, by means of increasing specific responsibility in this particular field and appointing dedicated and career ambassadors in countries which are strategically important in the objective of the European integration of the Republic of Moldova

7. the line of the 'justified ambition' of the Republic of Moldova in comparison with the European Neighbourhood Policy needs to be drawn more clearly by assuming many of the institutional responsibilities that lie behind joining the EU on the grounds that 'Moldova is an interested party'

8. the linguistic barriers need to be overcome, in particular the problem of speaking English or another European language, by all those experts who are involved in governmental activity; in general, translation is a problem which needs time and which generates non-synchronisation

9. there needs to be a differentiation between the 'Transnistrian case' and the 'European integration case'; the first cannot serve as an excuse for the non-resolution of the second.

\section{What does this tell us about perceptions in Moldova?}

It is certainly not good news that the EU has become more 'introverted' as regards enlargement in the last years, with signs of 'fatigue' being self-evident and apparent, it would seem, for three reasons:

a) there have been no success stories in the close vicinity of the EU (Ukraine, Moldova, Belarus, Georgia)

b) priorities are being driven on different vectors (the region is not combusting and there are no destabilising factors that would drive policy officials to take immediate measures)

c) internal reforms have stagnated, in spite of the formal self-congratulatory reports which have been submitted by the national governments in Ukraine and Moldova.

Nevertheless, the European Neighbourhood Policy has a huge gravitational impact on the conventionally-defined 'neighbours' as well as on Europe itself. First, there is a consensus that the eastern neighbourhood matters to Europe. Second, the European Neighbourhood Policy projects a huge soft-power irradiation as regards domestic actors and societies. Third, the eastern European neighbourhood is thereby decoupled from Russia's agenda and caprice, and for good reasons. One of these is because Russia does not have an Action Plan of its own, nor does it aspire to become an EU candidate, while almost every EU-Russia summit attests more to the accumulation of divergent than convergent views on an effective partnership between the two, even though the elements of a strategic partnership do remain.

Where Moldova is situated today, and how it seeks to define its own interests with the EU, is a question which is intensely debated, contested and challenged at different layers of society in Moldova. If you look at a map of Europe, then there is, on the face of it, no real reason to keep Moldova outside EU membership. Everything defines it as a south-east European state (language, culture, aspirations) and not as a pro-Russian satellite. If you go deeper and look into everyday administrative and economic business, then more questions need to be addressed - and not simple ones, either. 
First, there is a long list of issues that are today impeding the pace of domestic reform in Moldova. Laws are poorly implemented while the separation of powers lacks adequate clarity. The presidential veto in almost every aspect of public life further increases domestic tensions, prolongs some uncertainties and derails modernisation. With no effective sequencing of reforms, Moldova is challenged by too much election politics rather than state-building and effective policy-making efforts. The independence of the judiciary is still far off, while the weakness of the opposition reduces the potential for a real alternative, one that could really make a difference in Chişinau. To a large extent, this is due to the lack of a blueprint for domestic reforms, or otherwise a road map to diffuse EU knowledge and rationality. Such a blueprint had a major role in anchoring and stabilising central eastern Europe before 2004, and it now has a critical importance in the south-east European region, most of which are Stabilisation and Association Agreement states, excepting Moldova alone. Its almost-complete Action Plan is probably not the best instrument with which to target these much-needed reforms - first of all because of its unilateral character and secondly because of its strategic scarcity - but it does otherwise provide an incentive for domestic change.

First and foremost, however, the Action Plan does not provide any sign of a progressive advance towards EU membership - the juicy carrot that exerts a huge obsession amongst the people of Moldova. With no clear benchmarks for integration, i.e. lacking the conditionality template that proved successful in the case of the other new EU members, the intended effects of the unilaterally-imposed Action Plans in Moldova, as well as perhaps in Ukraine, Georgia, Armenia, etc., fail to deliver the essential incentives for domestic reforms. This places the success of this initiative at the discretion of the political elites, which tend to display their commitment on various occasions and with questionable levels of intensity. Thus, Moldova is losing the resource of time in which to transform itself as a state and as a society. Of course, Moldova will need more targeted help to support its transformation path. Not exactly in terms of a cost-benefit ratio, or in terms of humanitarian aid, but access to new programmes of technical assistance and the benefits of the 'Adaptation to Technical Progress' process, for example, as well as investment in the critical infrastructure of industry, roads and education that helped our central eastern European neighbours to become more predictable and productive.

We need, of course, a kind of mini-SAPARD to invest in the productive sector of the economy; we also need another type of technical support that would create incentives for a new public administration along the lines of the standards of EU governance. However, this cannot be done today unless new instruments are built. If we avoid speaking in terms of the acquis communautaire, we may dilute the sense of direction and European perspectives in Ukraine or Moldova, which could be rather counterproductive. The real question is 'How can we encourage reform in Moldova and Ukraine without granting an EU integration licence?' Ultimately, the answer could be the sectoral integration of the neighbours in various EU policies. Unfortunately, the European Neighbourhood Partnership Instrument seems to lack the flexibility and adequacy that might be needed; and, therefore, it seems to respond less well to the existing demands. 
The business community is becoming more and more aware of the benefits of the single EU market, since more than $50 \%$ of exports today are with EU member states. It would now be suicidal for any political party in Moldova to ignore or undermine future integration with EU, simply because the largest majority of citizens see Moldova as a European country which needs to be firmly located within the family of European states and not outside of it. Irrespective of the brand of party in power or, perhaps, in spite of this brand, we are strongly connected to what we now call the post-enlargement process of the EU. Our citizens, cultural activists and politicians discuss and address in a regular way how the EU operates, and its failures and victories are heavily debated in public, sometimes gaining more emoticons than the UEFA Championship. Moldova's voters support a pro-EU course, and this is very much supported by its trade in progress, by its increasing cultural and educational links and by its orientation. On its side, the EU acknowledges this aspiration and even praises some of Moldova's steps and policies, but spares no efforts to obstruct the insistent appeals of the authorities to obtain a ticket to the EU destination.

Formally, the EU says that the European Neighbourhood Policy does not lead to, but also does not exclude, EU membership. 'More partnership, less membership' - this is perhaps the tabloid message that has been regularly delivered to us since the European Commission launched its first Commission on the Wider Europe and then the European Neighbourhood Policy. The EU likes the process that has been initiated via the implementation of the Action Plan, but fears moving to a formal plan. We have witnessed a quite impressive list of statements that have elicited negative political opinions regarding further enlargement: 'Everything but institutions' (Romano Prodi), 'Constructive ambiguity as regards future integration', 'Time for to digest', etc. This poses a challenging factor for the core institutions of the present EU for, if any perspective cannot be granted today, there may be a future for it tomorrow. If the EU refuses to discuss perspectives of joining the EU, then it loses the moral legitimacy of influencing the process of transforming individual countries into modern, competent and responsible entities.

Clarity is needed concerning the long-term trajectory with the EU. The cost-benefit ratio between being an EU member or being its neighbour is totally different. With all due respect to those who developed the European Neighbourhood Policy, this does not provide sound incentives around which to galvanise the much-needed political and economic reforms. Clear conditionality mechanisms ought to reward the neighbours, not inhibit their efforts. Requesting vague 'reforms' and promising, no less vaguely, 'a stake in the single market' is not the way to proceed; therefore, compliance with specific and clear EU demands should lead to clear and attractive rewards. Otherwise, the danger of mimicked, rather than real, changes may undermine the effectiveness of the European Neighbourhood Policy and EU assistance policies. If the strong internal constituencies in Moldova support EU demands, then EU-supported policies are more likely to be implemented.

In this case, what is needed is an implicit co-ordination between EU policies and internal groups in Moldova. If, for example, the EU promises greater trade opportunities for Moldova in exchange for compliance with certain demands, then this might mobilise business groups in Moldova to lobby the government to comply with EU demands, if 
such groups were likely to benefit from greater possibilities of trade. What Moldova needs, first and foremost, is the possibilities of increased trade with the EU rather than direct financial assistance. However, the rewards should be attractive, both in symbolic as well as practical terms. They should also show that compliance with the requests of the EU is beneficial for business and for ordinary citizens and that nobody can 'monopolise' the relationship with the EU.

It is something perhaps rather prosaic, but EU assistance should be directed towards strengthening the pro-reform and pro-democracy constituencies, including civil society groups and business actors. This certainly means the challenge of improving or regaining the freedom of movement of citizens, which exists in contrast to the oft-pronounced statements that the European Neighbourhood Policy has aimed in practice to avoid new divisions in Europe. The creation of a single visa facilitation centre is a positive, but quite modest, step. In this way, we have been deprived of one of the major postcommunist gains: open borders with the west and the chance to travel without slow, expensive and often humiliating visa procedures. Many would say that people became suspicious when freedom of movement, one of the four freedoms promised by the April 2003 Commission on the Wider Europe, was excluded from the package of bilateral benefits of the European Neighbourhood Policy, being replaced by an ordinary benefit to be negotiated on bilateral terms. It was upsetting that other countries, such as Russia, had already in 2004 gained a priority visa facilitation regime with the EU, without any prior conditionality, and long before any other EU neighbouring countries had signed their Action Plan with the EU.

Moldova can be seen as a challenging case for the EU, and for the architects of the European Neighbourhood Policy as well, for at least two (partially linked) factors: first, the pace of domestic reforms; and second, the protracted conflict in its eastern rayons. However, it can be a brilliant example of 'hard cases' recovered by the EU from the legacy of a past which is trying to respond to new Russian hegemonic ambitions, from the cold war militaristic instincts shared in Tiraspol or elsewhere, as a kind of new 'bible' of brute force. Nevertheless, the involvement of the EU in conflict resolution in Transnistria has already shown a huge virtue of the EU's 'soft power' effects. Thus, increasing the pressure on the sides that fomented the military conflict, that inspired and inflamed the 1992 rebellion, will only lead to the transformation of that conflict via a strengthening of the advantages of Moldovan state performance and EU democratic conditionality. To succeed, the European Neighbourhood Policy needs to lead to an enhanced partnership agreement, designed to award privileges to those who have reached the standards of initiating formal talks with the EU on integration, and on a genuine meritocratic basis. 